\title{
PROCESSING INFORMATION IN THE GO/NOGO/GO PARADIGM: INTERACTIONS BETWEEN COGNITIVE FUNCTION AND THE AUTONOMIC NERVOUS SYSTEM
}

\section{PRZETWARZANIE INFORMACJI W PARADYGMACIE GO/NOGO/GO: INTERAKCJE POMIĘDZY FUNKCJĄ POZNAWCZĄ I AUTONOMICZNYM SYSTEMEM NERWOWYM}

\author{
Volodymyr Lyzohub ${ }^{1(\mathrm{~A}, \mathrm{C}, \mathrm{D}, \mathrm{E}, \mathrm{F})}$, Tetiana Kozhemiako ${ }^{1(\mathrm{D}, \mathrm{F})}$, \\ Ahmet Alperen Palabiyik ${ }^{2(B, C, D)}$, Serhii Khomenko ${ }^{1(C)}$, Svitlana Bezkopylna ${ }^{1(A, B, C, E, F)}$ \\ ${ }^{1}$ Bohdan Khmelnitsky National University, Cherkasy, Ukraine \\ ${ }^{2}$ Department of Nursing, Faculty of Health Sciences, Ardahan University, Ardahan, Turkey
}

Authors' contribution Wkład autorów:

A. Study design/planning zaplanowanie badań

B. Data collection/entry zebranie danych

C. Data analysis/statistics dane - analiza i statystyki D. Data interpretation interpretacja danych E. Preparation of manuscript przygotowanie artykułu F. Literature analysis/search wyszukiwanie $i$ analiza literatury G. Funds collection zebranie funduszy

\section{Tables: 0}

Figures: 6

References: 29

Submitted: 2020 Jan 20

Accepted: 2020 Feb 20

\section{Summary}

Background. The association between cognitive function and the autonomic nervous system (ANS) was studied using a go/nogo/go paradigm. Material and methods. Cognitive tasks involved determining signal modality, visual shapes or word meaning, as well as quick error-free reactions with the left (gol) or right (gor) hand or motor inhibition (nogo). The rate of signal presentation increased gradually $(30,60,90$ and 120 per minute). The ANS was examined based on heart rate variability (HRV), scattergram area (S), periodic (SD2) and aperiodic (SD1) oscillations of correlation rhythmography (CR). Results. Differentiation of verbal and visual cues presented at a low rate was associated with increased activity of cognitive and neurophysiological mechanisms of ANS regulation, coordinated sympathoparasympathetic interaction, and enhanced integrative processes. High rate presentations led to divergent changes in cognitive function and ANS: increased HRV and decreased SD1 and SD2, increased number of errors, and decreased motor reaction time and S. Conclusions. Interactions between cognitive function and ANS were related to the rate of presentation and signal modality: increased interactions occurred with low rate presentations, whereas, high rate (visual) presentations impaired performance and also reduced autonomic-cognitive interactions.

Keywords: neurocognitive tests, autonomic nervous system, heart rhythm variability, go/nogo/go paradigm

\section{Streszczenie}

Wprowadzenie. Zbadano interakcje pomiędzy funkcją poznawczą i autonomicznym systemem nerwowym (ANS) pod względem przetwarzania w paradygmacie go/nogo/go. Materiał i metody. Zadania poznawcze obejmowały określenie modalności sygnału, kształtu figur lub znaczenia słowa i szybką, bezbłędną reakcję dotyczącą lewej (gol) lub prawej (gor) ręki bądź hamowania czynności motorycznych (nogo). Szybkość prezentacji sygnału wzrastała stopniowo od 30, przez 60 i 90, aż do 120 na minutę. Autonomiczny układ nerwowy był badany zgodnie ze wskaźnikami regulacji częstości akcji serca: częstością HRV, obszarem regulacji (S), okresowymi (SD2) i nieokresowymi (SD1) oscylacjami rytmografii korelacyjnej (CR). Wyniki. Zróżnicowanie sygnałów ustnych i sygnałów wizyjnych o niskim tempie charakteryzowało się zwiększeniem aktywności w kognity wnych i neurofizjologicznych mechanizmach regulacji ANS, skoordynowaną interakcją połączenia sympatyczno-przywspółczulnego oraz usprawnieniem procesów integracyjnych. Prezentacja z wysoką częstotliwością doprowadziła do przeciwnych zmian funkcji poznawczych i ANS: zwiększyło się tętno i zmniejszyło SD2 i SD1, zwiększyła się też liczba błędów i zmniejszył czas reakcji motorycznych i S. Wnioski. Odkryto zależność od wzajemnego powiązania funkcji poznawczych i ANS przy trybie prezentacji i modalności sygnału: interakcja wzrosła przy niskim trybie, z kolei niedobór aktywacji mechanizmów neurokognitywnych i autonomiczno-poznawczych został stwierdzony przy dużej częstości sygnałów obrazowych.

Słowa kluczowe: testy neuropoznawcze, autonomiczny układ nerwowy, częstość akcji serca, paradygmat go/nogo/go

Lyzohub V, Kozhemiako T, Palabiyik AA, Khomenko S, Bezkopylna S. Processing information in the go/nogo/go paradigm: interactions between cognitive function and the autonomic nervous system. Health Prob Civil. 2020; 14(1): 53-62. https://doi.org/10.5114/hpc.2020.93294

Address for correspondence / Adres korespondencyjny: Volodymyr Lyzohub, Bohdan Khmelnitsky National University, 81 Shevchenko Boulevard, 18031 Cherkasy, Ukraine, e-mail: v_lizogub@ukr.net, phone: +380 (0472) 372142

ORCID: Volodymyr Lyzohub https://orcid.org/0000-0002-3001-138X, Tetiana Kozhemiako https://orcid.org/0000-0003-4752-4197, Ahmet Alperen Palabiyik ORCID: Volodymyr Lyzohub https://orcid.org/0000-0002-3001-138X, Tetiana Kozhemiako https://orcid.org/0000-0003-4752-4197, Ahmet Alperen Palabiyik
https://orcid.org/0000-0002-8199-390X, Serhii Khomenko https://orcid.org/0000-0003-0918-8735, Svitlana Bezkopylna https://orcid.org/0000-0003-2603-2820 Copyright: (C) Pope John Paul II State School of Higher Education in Biała Podlaska, Volodymyr Lyzohub, Tetiana Kozhemiako, Ahmet Alperen Palabiyik, Serhii Khomenko, Svitlana Bezkopylna. This is an Open Access journal, all articles are distributed under the terms of the Creative Commons Attribution-NonCommercialShareAlike 4.0 International (CC BY-NC-SA 4.0) License (http://creativecommons.org/licenses/by-nc-sa/4.0/), allowing third parties to copy and redistribute the material in any medium or format and to remix, transform, and build upon the material, provided the original work is properly cited and states its license. 


\section{Introduction}

According to the World Health Organization (WHO), the dissonance of neurocognitive and autonomic mechanisms underlies the development of depression, leads to a decrease in working capacity, an increase in disability, and a deterioration in quality of life [1]. Therefore, studying the interaction between cognitive functions and the autonomic nervous system (ANS) in terms of processing complex information, is an important area of focus. In order to understand the mechanisms of regulation, to identify information indicators of the functional state of the brain, and to prevent the deterioration of health, it is important to investigate the influence of information loads of different complexities on the interaction of cognitive functions and the ANS.

Cognitive assignments require the processing of information arriving from different afferent channels and rates. Simple and complex motor reactions can be investigated through differentiation tasks, i.e. go/go (simple) and stop-signal and go/nogo (complex). This task specifically measures the ability of an individual to cancel motor activity, even after initiation of response - thus, providing a measure of inhibitory control [2-5]. To evaluate the regulatory functions of the ANS, the method of heart rate variability (HRV) can be applied [6].

Integrative functions of cognitive systems can be studied by utilizing variants of the two-stimulus go/nogo tasks [7, 8]. For instance, such dual tasks are used in the diagnosis of Alzheimer's disease, Parkinson's disease, schizophrenia, dementia, hypo-frontality, and hyperactivity, as well as for risk assessment of behavior in extreme conditions [7, 9, 10]. A three-stimulus differentiation task, such as the "gol/nogo/gor" paradigm (a differentiating reaction with the left/right hand (gol/gor) and inhibition of a motor action (nogo)), is used to assess more complex cognitive processing that requires constant switching of the focus of attention, processing signals in working memory, and the emergency construction of a response program [11]. The three-stimulus sensorimotor task is thought to link the effectors of the neurocognitive networks responsible for the interaction of analyzer, motor, and motivational systems of the brain. Brain sensorimotor integration is measured qualitatively by reaction accuracy; whereas, reaction time acts as a quantitative characteristic. The qualitative interaction of brain cognitive systems can be assessed in terms of the number of errors committed during the task $[5,12]$.

The neuro-emotional and autonomic components of cognitive processing are associated with the activation of regulatory functions of the ANS. Studying visceral functions of the nervous system requires consideration of the roles of cortical structures in orientation and the mobilization of attention and memory features, including the ANS in terms of heart rate $[12,13]$. During the processing of complex information from different modalities in the go/nogo/go task, both differentiation and switching the focus of attention are known to be accompanied with changes in the interactions of neurocognitive systems of the brain [2,3] and changes in quantitative and qualitative regulation of the cardio-vascular system $[14,15]$. Relevant measures include diagnostic and prognostic value from HRV analysis and characteristics of correlation rhythmography (CR) [16, 17]. This method allows for discrimination between periodic and aperiodic oscillations of HRV on the Poincaré-Lorenz graph $[6,15]$.

Analysis of existing studies shows that results differ depending on individual characteristics of subjects, task type, activity conditions, and the speed of stimulus presentation. Despite significant progress in studying individual elements of the brain and the systems that support it during the processing of information of different complexities and modalities, there is not a clear understanding of how the interaction of brain systems results in successful cognitive activity or of the brain systems' interplays with regulators of the ANS. Successful complex multi-modal information processing is associated with both increasing and decreasing coherence of neurocognitive and neuroautonomic regulatory links [2-5, 7-13]. In general, the results are conflicting without distinguishing clear correlates for the processing information of different complexities and modalities in cognitive systems with neuroautonomic support. Therefore, the goal of the research is to find out the peculiarities of cognitive functions and their relation to the regulatory mechanisms of the ANS in terms of differentiating visual and verbal information in the go/nogo/go mode at different rate of signal presentation.

\section{Material and methods}

The correlation of cognitive and autonomic nervous systems was studied in 56 medical students, aged 16-17 years, who provided informed consent in accordance with the World Health Association Helsinki Declaration of 1964. Cognitive activity was investigated using the computer system "Diagnost-1M" in the "imposed rhythm" mode [11]. A neurophysiological three-stimulus task in which the subject differentiated image and verbal stimuli in the go/nogo/go paradigm with random (33\%) presentation of response cues (go) and non-response cues (nogo signal), was used [12].

The task consisted of two tests: I - to determine error number and motor reaction speed for shapes; II - to determine error number and motor reaction speed for words. The subjects received an instruction to press the left button with the thumb of the left hand (gol) when a circle or a plant name appeared on the screen, to press 
the right button with the right hand (gor) when a square or an animal name appeared on the screen and not to press any button (nogo) when a triangle or an object name (inhibitory stimulus) appeared on the screen. Testing started with the image stimulus presentation at rate of 30 signals per minute. Then, signal presentation rate increased by 30 frames and progressed to 60,90 , and 120 stimuli per minute. The interstimulus interval varied randomly from 0.01 to $0.4 \mathrm{~s}$ for each task group. Rest between tasks was 30 seconds. When performing the tests, attention was paid to the success of the subject's performance, to the prevention of errors, to omissions of signals, to delayed or advanced reactions and to the maximum speed of the motor reaction. A 60-second signal differentiation was used for cognitive load. The order and timing of signal presentation varied and was random. The exposure time of a signal was $0.5 \mathrm{~s}$, and the pause time was changed randomly by the algorithm based on the software. After rest, the tasks were repeated for verbal stimuli [12].

To assess ANS function, correlation rhythmography (CR) was used (Holter monitor, KhAI MEDICA). Measurements for HRV, periodic and aperiodic oscillations, and characteristics of CR were determined at rest and while performing the task during the gradually increased rate of image and verbal signal presentation [6, $15,16]$. Frequency of heart rate was recorded (HR, bpm); the maximum amplitude of periodic oscillations was determined (SD2 ms) showing the activation of the parasympathetic division; the amplitude of the aperiodic oscillations of R-R intervals was represented by the transverse axis of the scattergram (SD1 ms) showing the sympathetic activation; and the scattergram area $\left(\mathrm{S}, \mathrm{ms}^{2}\right)$ using the formula of $\mathrm{S}=(\mathrm{n} \times \mathrm{l} \times \mathrm{w}) / 4$ was determined representing total activity of both divisions of autonomic regulation $[6,15,16,17,18]$.

Statistical verification of the normality of data distribution was performed using the Shapiro-Wilk test. HRV data are represented by the median, first and third quartiles ( $25 \%$ and $75 \%$ percentiles). The reliability of the differences between the samples, in the case of normal distribution, was evaluated by the Student's test, and in the case of nonparametric distribution, using the Wilcoxon and Mann-Whitney criteria. According to the Shapiro-Wilk test, the number of errors and the speed of reaction were parametric, and the heart rate variability indicators were non-parametric. The significance of probable values was assumed to be $\mathrm{p}<0.05$.

\section{Results}

The results of cognitive tests revealed that the speed of motor reaction and the quality (number of errors) of multimodal information processing in the gol/nogo/gor task depended on the rate of stimuli presentation. As the rate of signal presentation increased, there was an increase in the number of errors and a decrease in the motor reaction time (Figure 1). Figure 1 shows that the number of false reactions increased with the increasing rate of information presentation at 30 and up to 60,90, and 120 stimuli per minute. The smallest number of errors were made at the presentation rate of 30 stimuli per minute and the largest number of errors at 120 stimuli per minute. The number of false reactions in the gol/nogo/gor differentiation task were found to be statistically significantly less for image stimuli compared to verbal stimuli $(\mathrm{p}<0.034-0.047)$.

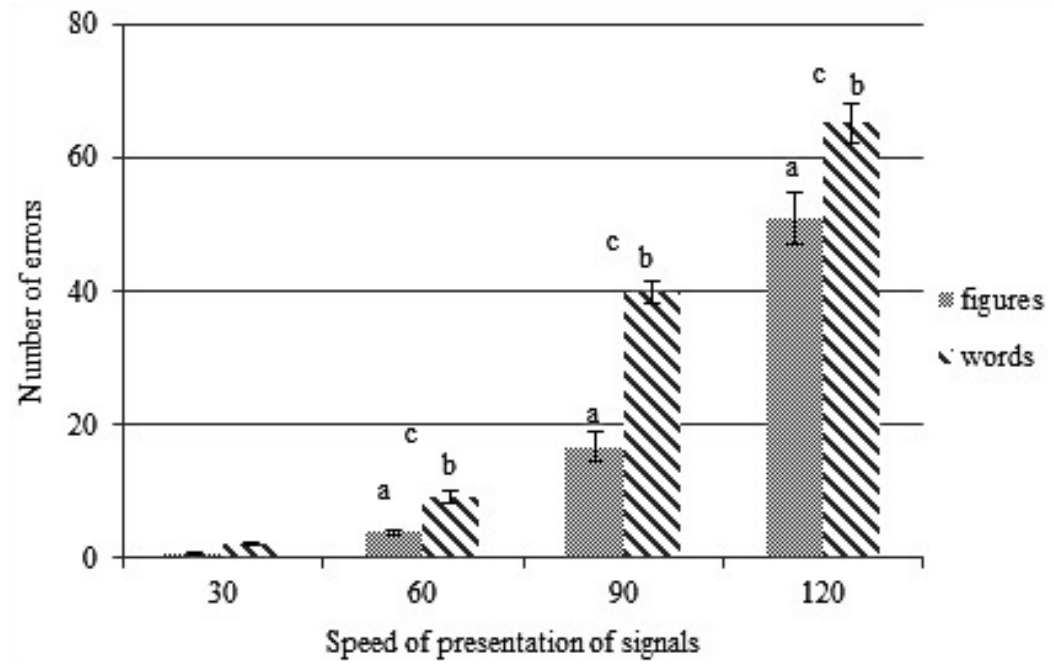

Figure 1. Number of errors while responding to image and verbal stimuli in a cognitive test

Note: a - statistically significant differences in the number of errors at different speeds of presentation of figures compared to 30 stimuli per minute; b - statistically significant differences in the number of errors at different speeds of presentation of words compared to 30 stimuli per minute; c - statistically significant differences in the number of errors at different speeds of presentation between figures and words. 
Analysis of motor reaction time in the gol/nogo/gor task showed a decrease in the time of sensorimotor reaction with gradually increased rate of stimuli presentation (Figure 2). The motor reaction time while performing cognitive tasks ranged from $267.4 \pm 24.7-373.0 \pm 70.5 \mathrm{~ms}$ for image stimuli and 271.3 $\pm 62.0-580.3 \pm 78.8$ $\mathrm{ms}$ for verbal stimuli. The reaction time was the highest in tasks with a presentation of 30 stimuli per minute at $373.0 \pm 70.5 \mathrm{~ms}$ for images and $580.3 \pm 78.8 \mathrm{~ms}$ for verbal cues. Motor reaction time gradually decreased with increasing rate of stimuli presentation and achieved the highest values at rate of 120 signals per minute being 267.4 $\pm 24.7 \mathrm{~ms}$ for image stimuli and $271.3 \pm 62.0 \mathrm{~ms}$ for verbal.

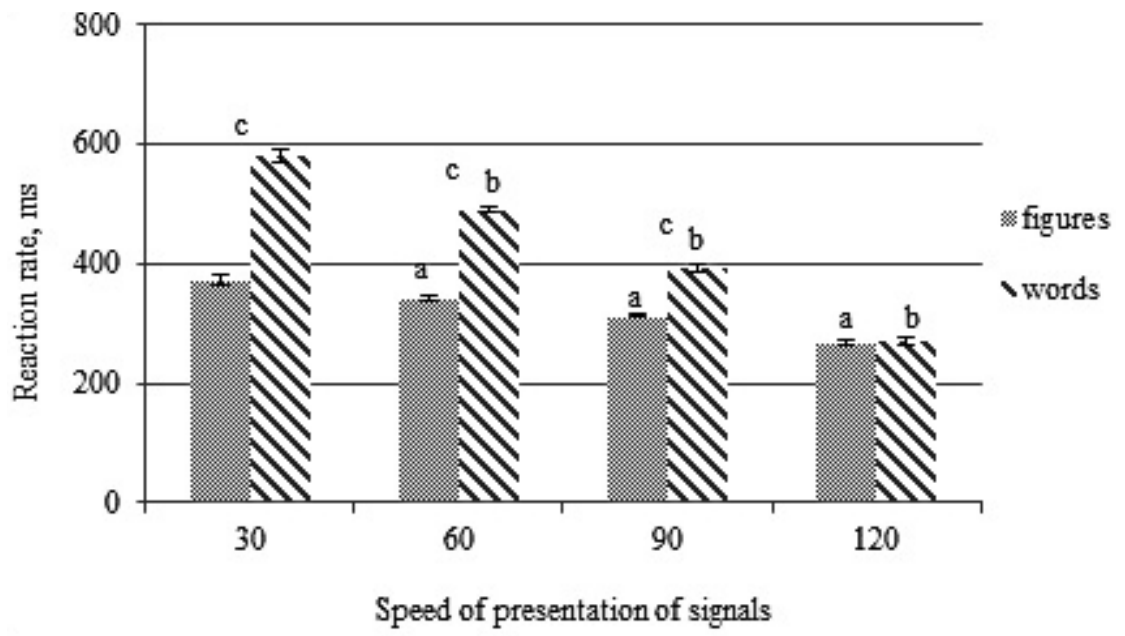

Figure 2. Reaction rate while responding to image and verbal stimuli in a cognitive test

Note: a - statistically significant differences between the processing speed of figures at different presentation rates compared to 30 stimuli per minute; b - statistically significant differences between the processing speed of words at different presentation rates compared to 30 stimuli per minute; c - statistically significant differences between the processing speeds at different presentation rates between figures and word tasks.

The results gol/nogo/gor task revealed statistically reliable differences between the reaction times to image and verbal stimuli. The reaction time for image stimuli in the tests at 30,60, and 90 stimuli per minute was less than for verbal stimuli $(\mathrm{p}<0.034-0.047)$. The reaction time for image and verbal stimuli at 120 signals per minute was the least and did not differ between image and verbal stimuli ( $p>0.065)$.

Based on CR results the activation of the ANS was dependent on the rate of stimulus presentation. The HRV analysis showed a gradual increase in $\operatorname{HR}(\mathrm{p}<0.01-0.001)$. In the task with a gradual increase in presentation rate from 30 to 60, 90, and 120 stimuli per minute, the indicators of S, SD2, and SD1 decreased ( $<<0.047-0.012)$. Figures 3, 4 and 5 show the changes in HR and indicator dynamics of HRV analysis according to S, SD2 and SD1 characteristics. The lowest HR values of 72 [69; 75] bpm were found at rest; they gradually increased with increasing stimuli presentation rates of 30,60, and 90 signals per minute and maximum HR values were achieved at 120 stimuli per minute at 83 [77; 89] bpm for image stimuli and 83 [78; 89] bpm for verbal stimuli. There were no reliable between factor differences in HR for verbal stimuli and image stimuli at rates of 30, 60, 90, and 120 stimuli per minute $(p>0.072)$. 


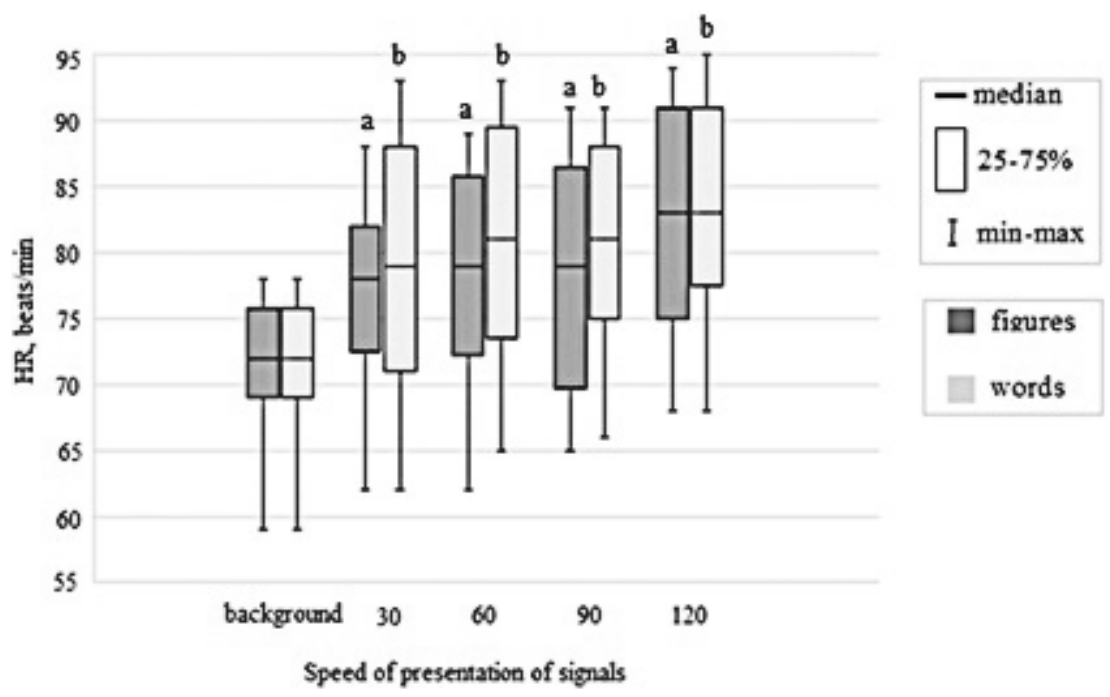

Figure 3. HR dynamics versus increased rate of image and verbal stimuli presenting Note: a - statistically significant differences in HR versus background for figure stimuli; $\mathrm{b}$ - statistically significant differences in HR versus background for figure stimuli.

While performing a cognitive task with a gradually increased stimuli presentation rate from 30 to 60,90 and 120 stimuli per minute, a deceleration of SD2 was observed $(\mathrm{p}<0.01-0.001)$ (Figure 4). The highest values for SD2 $(236[166 ; 272] \mathrm{ms})$ were found with a stimuli presentation rate of 30 per minute; this indicator decreased by $55-65 \%$ with increasing presentation rate. SD2 for verbal and image stimuli was similar; statistical differences were not found ( $p>0.067-0.081)$. The results showed that a gradual decrease of SD2 indicated the effect of increasing cognitive load on periodic oscillations in HR and a decrease in activation of the parasympathetic section of the ANS [16-18].

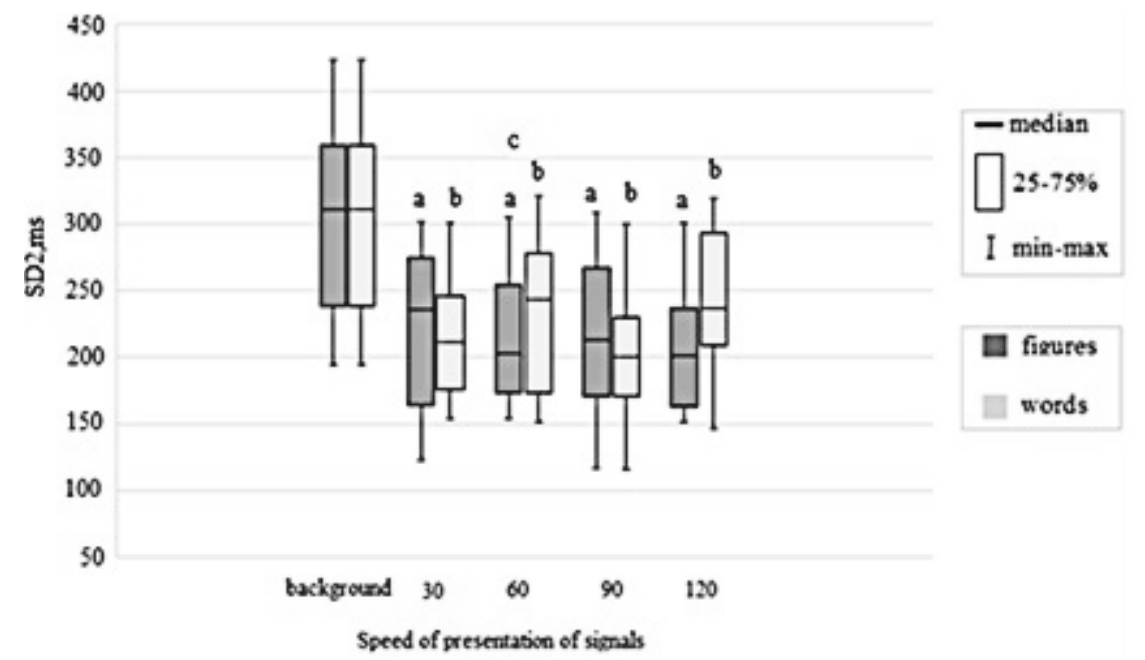

Figure 4. SD2 dynamics of correlation rhythmography for increased rates of presentation of image and verbal stimuli Notes: a - statistically significant differences of SD2 at different figure processing speeds versus the background; $b$ statistically significant differences of SD2 at different word processing speeds versus the background; c - statistically significant differences between figure stimuli and word stimuli for SD2 at different processing speeds.

The analysis of aperiodic oscillations in CR (Figure 5) during an increasing rate of stimuli presentation, both verbal and image, showed a gradual decrease of SD1 ( $p>0.059)$. The highest values for SD1 (117 [76; 160$]$ ms) were observed at 30 stimuli per minute and at higher presentation rates of 60 and 90 stimuli per minute the amplitude of aperiodic oscillations for SD1 gradually decreased (10-25\%) and reaching their lowest values of 102 [89; 113] ms for verbal stimuli and 107 [77; 127] $\mathrm{ms}$ for verbal stimuli at the 120 stimuli per minute rate. There were no statistically significant differences for amplitude of SD1 aperiodic oscillations while processing image and verbal information ( $p>0.073$ ). The above results can be summarized as enhancing the effect of increasing 
cognitive load on the sympathetic part of ANS. The gradual decrease in amplitude of SD1 aperiodic oscillations reflects the decrease in activation of the sympathetic division of the ANS $[6,17,18]$.

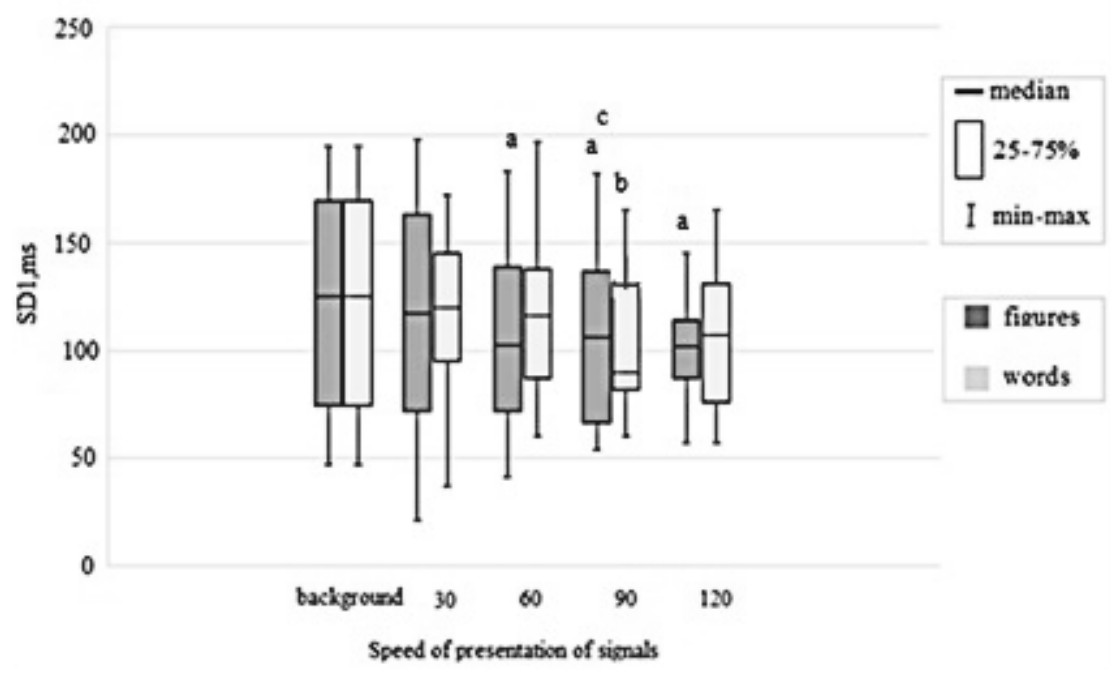

Figure 5. SD1 dynamics of correlation rhythmography for increasing rates of image and verbal stimuli presentation Notes: a - statistically significant differences of SD1 at different speeds of figure processing versus background; b - statistically significant differences of SD1 at different speeds of word processing versus background; c - statistically significant differences between figure stimuli and word stimuli for SD1 at different processing speeds.

The increase in the rate of processing cognitive information in gol/nogo/gor task was accompanied by a decrease in scattergram area, S (Figure 6). The highest scattergram area values were found at a rate of 30 stimuli per minute with 17,530 [16420; 23743] $\mathrm{ms}^{2}$ for verbal stimuli. With the increased presentation rate of 60 and 90 stimuli per minute, the area on the scattergram, reflecting regulation, decreased by $30 \%$ and $40 \%$ and reached the lowest value of 13,249 [12928; 14059] $\mathrm{ms}^{2}$ at 90 per minute for the verbal stimuli and 15,872 [11949; 18365] $\mathrm{ms}^{2}$ at 120 per minute for image stimuli. When performing test tasks with a presentation rate of 30 and 60 per minute, the area of the scattergram showed no statistical differences between verbal and image stimuli $(p>0.072)$. With the increased presentation rate of 90 stimuli per minute, the scattergram area became statistically higher for image versus verbal stimuli $(\mathrm{p}<0.013-0.025)$. With the presentation rate of 120 stimuli per minute, the area, representing autonomic regulation of heart rate, was reliably higher for verbal stimuli than image stimuli $(\mathrm{p}<0.024)$. The decrease in the $\mathrm{S}$ indicator while performing the cognitive task of processing information with a gradual increase in presentation rate confirms increased stress on the HR regulatory systems, also reflected by decreased periodic and aperiodic oscillations in cardio intervals. This suggests that the gradual decrease in scattergram area is an effect of increased cognitive load which decreased the activation of ANS, both its parasympathetic and sympathetic links $[16,17]$. 


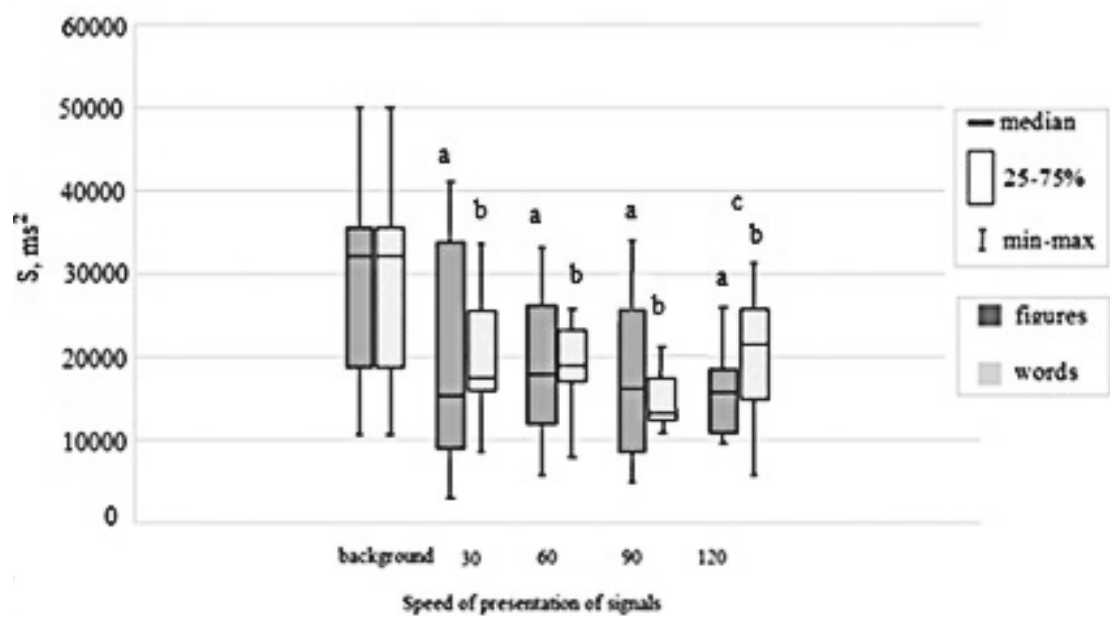

Figure 6. S dynamics of correlation rhythmography for increasing rates of presenting image and verbal stimuli Notes: a - statistically significant differences of $S$ at different presentation speeds of figures versus background; $b$ statistically significant differences of S at different presentation speeds of words; c - statistically significant differences between figure stimuli and word stimuli for $\mathrm{S}$ at different presentation speeds.

Thus, functional interaction of the cognitive and autonomic nervous systems, the success and speed of processing information, depends on the rate of presentation and modality of cognitive stimuli.

\section{Discussion}

The analysis of the results shows that functional interaction of cognitive and autonomic nervous systems during processing of information in the gol/nogo/gor task depends on the presentation rate of stimuli and their modality. The gradual increase in differentiation rates of image and verbal stimuli in the gol/nogo/gor task from 30 to 60 stimuli per minute was found to increase the activation and integration of cognitive functions and regulation mechanisms of ANS. One might think that the subjects, when differentiating the signals in the gol/ nogo/gor task with an increased rate of stimulus presentation from 30 to 60 per minute, have a subconscious ability to increase the speed of motor reactions with a small number of errors. That the subjects only exhibited a few errors (3-5\%) at this rate of stimulus presentation, shows they had time to perceive, analyze and respond to the information load correctly. Processing information at this rate is likely within the functional speed constraints of the nervous system, which is inherent to each subject [11,19], corresponding the optimal ratio between the rate of signal presentation, the speed of motor reaction and the number of errors. This indicates that in the cerebral cortex, there is neurointegration which is characterized by information synthesis, a focused interaction of a large number of neurons (networks/columns) that discharge in the same rhythm [20]. We can assume that in neuronal networks, there are optimal processing pathways of interaction for image and verbal signals. When presented with stimuli at a rate of 90 per minute for verbal and 120 per minute for images, most subjects could not correctly process the information because the rate of the presented stimuli exceeded the functionality of the nervous system $[19,20]$. Each subsequent stimulus entering the central nervous system for differentiation was met with system already in a state of excitation from the previous stimulus. Under conditions of rapidly presented stimuli, the subjects had insufficient time to analyze the information and prepare to perceive a new signal, which led to the high psychophysiological stress. Despite the maximum rate of motor reactions and the mobilization of psychophysiological functions, the subjects made a great number of errors (21-32\%); this measure demonstrates a significant decrease in the quality of task performance and a predominance of inhibitory processes $[10,19,20,21,22]$. Tasks exceeding the optimum rate of presenting information result in dissonance in the cognitive systems of the brain and may contribute to the development of fatigue and pathological conditions.

Our results confirm that the success of processing information and the speed of reaction to stimuli depends on the modality of signals. The number of errors was statistically higher and the reaction speed was lower during the processing of verbal information versus image stimuli, indicating the involvement of various neurophysiological mechanisms. According to the literature, the speed of performing a cognitive task depends on the type, form, signal modality and complexity of the task [7, 10, 19, 20,21]. In this cognitive test, we used visual images (geometric shapes) and verbal stimuli (word meanings) which are assigned to different signal 
systems and afferent channels $[23,24]$. The subjects had to react as quickly as possible by pressing the button of the remote with the left or right hand upon the appearance, according to the instruction of the stimulus modality, of the shape of the figure or the meaning of the word. The cognitive task performance of gol/nogo/gor using geometric figures was, on average, $64 \%$ higher than using words $(\mathrm{p}<0.042)$, and the success rate using image stimuli was $13 \%$ higher than verbal stimuli $(\mathrm{p}<0.034)$. We assume that processing verbal information in the gol/nogo/gor task, includes the ability to determine the semantic meaning of words, switching attention, mapping stimuli in memory, compiling an action program, a left (gol) or right (gor) quick reaction, or restraining from a motor reaction (nogo) [20,22]. Therefore, the speed of performing a cognitive task in the three-stimulus paradigm gol/nogo/gor is faster for image stimuli than for verbal stimuli $(\mathrm{p}<0.023-0.043)$. The greater success in task performance using image stimuli can be explained with the hypothesis that, at the stage of primary selection of signal modality, two neuron systems are involved: the magno-pathway, being sensitive to stimuli with temporal characteristics, and the parvo-pathway, sensitive to information with spatial characteristics [23, 24]. The differences in the number of errors and the speed of reaction to image and verbal stimuli entering the brain are probably caused by different speeds of information transmission through magno- and parvo-pathways. Image signals are likely transmitted along the axons of parvocellular and magnocellular systems with a higher speed than verbal stimuli $[23,24]$.

Differences in image and verbal stimuli analysis can be further explained when considered in terms of Pavlovian signaling systems. Image processing is occurs in the first signaling system characterized by flexibility, ease of switching attention and high sensorimotor integration and automation [7, 12]. In contrast, verbal functions are associated with the operation of the second signaling system, which is more corticalized in the frontal areas, less stable and has limited neurophysiological resource [7, 25].

It should be noted that an increase in the presentation rate of cognitive information was accompanied by a gradual increase in the number of errors, a significant increase in HR, a decrease in reaction time, and a decrease in S, SD2, and SD1. An increase in the presentation rate of cognitive image and verbal information in the gol/nogo/gor task gradually enhanced the activity of heart rate regulation mechanisms. It was found that the faster the signals were presented, the higher the observed activity of HR regulation mechanisms. Low values of HR and high values of CR S, SD2 and SD1 were registered in the background and at rate of 30-60 stimuli per minute. At a rate of 90-120 stimuli per minute, the indicators of S, SD2 and SD1 decreased to their lowest values, and HR achieved a maximum level. It is noteworthy that an increase in the activity of the ANS in response to the gradual increase in the rate of information presentation occurred not by activating the sympathetic division but by more pronounced changes in its parasympathetic division. This was supported by the fact that, in response to an increase in information presentation rate, the changes of SD1 were less pronounced than for SD2, decreasing by $12-15 \%$ and $50-60 \%$, respectively. The observed asymmetry in HRV reflects different contribution of periodic and aperiodic oscillations in HR to the general variability. The results of our investigation and the concept of vagal asymmetry of $\operatorname{HR}[16,26]$ allow for the assumption that the vagal complex was involved in removing the inhibitory effect of the sinoatrial node. Most likely, the cardiovascular system function increases when processing information with a gradually increasing rate of presenting information due to an increase in the activity of the vagus nerve of the ANS removing the inhibitory effect of the sinoatrial node, thereby preserving the body's metabolic resources without involving more significant metabolic costs $[16,26]$. Therefore, the increase in HR in cognitive tasks with increased rate of stimuli presentation primarily occurred due to more pronounced changes in the parasympathetic division of the ANS.

Other explanations of asymmetry in HR regulation, when performing tasks with gradual increased presentation rates of stimuli of different modalities, include differential sensitivity of baroreflex to the increase and decrease in blood pressure [16], the mechanical mechanism of asymmetry of respiratory sinus arrhythmia $[26,27]$, and other mechanisms of asymmetry: changes in action potential, concentration of potassium and sodium in the sinoatrial node, and the concentration of acetylcholine and adrenaline or other mediators [28].

The gradual increase in the differentiation rate in the gol/nogo/gor task for verbal stimuli from 30 to 60 per minute and for image stimuli from 30 to 90 stimuli per minute was found to result in increased activation of regulatory mechanisms of the ANS, their coordinated interaction and enhanced integrative processes. Differentiation of positive and inhibitory stimuli at the latter rates was accompanied by a moderate (5-9\%) number of errors, a high rate of motor reaction, and the coordinated increase in activation processes of the ANS, with parasympathetic activation predominating [15].

An increase in the rate of presented information in the gol/nogo/gor task to 90 per minute for verbal stimuli and to 120 signals per minute for image stimuli led to weakened cognitive interaction and decreased activation of the ANS and is characterized by multidirectional changes in HR regulation. According to the CR results, an increase in HR in response to significant increase in the rate of information presentation was accompanied by 
a decrease in the scattergram area and ANS regulation, the occurrence of asymmetry in periodic and aperiodic oscillations of $\mathrm{HRV}$, and an increase in the rate of motor reactions, which coincides with the significant number of false reactions indicating the occurrence of interference [12], cognitive dissonance [29], and vegetative cognitive disintegration [10]. The imbalanced ANS resulting from reduced activation in parasympathetic and sympathetic divisions may indicate the predominant protective type of regulation [15].

This research shows that the interaction of neurocognitive brain systems associated with perception, analysis and motor functions, as well as the activation of autonomic mechanisms of heart rate regulation while processing information depend on the rate of stimulus presentation and modality. Integrative functions of neurocognitive brain systems and the ANS are most pronounced when information is presented at a rate of 30 and 60 stimuli per minute for verbal cues and 60 and 90 per minute for images. Our results confirm that there is not only information integration but vegetative and metabolic synthesis under such conditions [10]. We should emphasize that information metabolism in the interaction of neurocognitive brain systems and their operational components do not only play an energetic role reflected in conservative changes of the ANS. The subjects cannot process information successfully and create some operational order from chaos at high rate of presenting information; there is a cognitive dissonance [29] and vegetative cognitive interference [12].

\section{Conclusions}

Functional interaction of cognitive and autonomic nervous systems while processing information in the gol/ nogo/gor task was dependent on the rate of stimulus presentation and modality. The interaction of cognitive and autonomic systems increased with increased rate of stimulus presentation up to 60 per minute for verbal stimuli and up to 90 per minute for images. When the differentiation rate increased to 120 per minute for image stimuli and 90 per minute for verbal cues, vegetative cognitive interference and cognitive dissonance occurred.

The success of processing information and the rate of motor reaction depended on signal modality. The number of mistakes and the time of motor reaction were statistically higher while processing verbal information compared to image cues. The motor reaction times to both image and verbal stimuli were highest with the differentiating rate of 120 stimuli per minute.

The gradually increased rate of for differentiating verbal stimuli, from 30 to 60 per minute, and for image stimuli, from 30 to 90 per minute, caused an increase in the activation of regulatory mechanisms of ANS and in the coordinated interaction of sympathetic and parasympathetic links and enhanced the integrated processes.

In the gol/nogo/gor task, increasing the rate of information presentation to 90 verbal stimuli per minute and 120 image stimuli per minute weakened interactions between cognitive processes and decreased the activation processes of ANS characterized by multidirectional changes in the HR regulation. According to CR results, an increase in the HR in response to a significant increase in the information presentation rate was accompanied by a decrease in scattergram area and the occurrence of asymmetry for the periodic and aperiodic oscillations in HRV. An increase in the rate of motor reactions coincided with a significant increase in the number of false reactions, indicating the occurrence of cognitive dissonance and vegetative cognitive interference.

These research results can be used for prognostic evaluation of human cognitive activity in conditions of complex information loads, in the detection of hypofrontality, in hyperactive and deviant children with attention deficits, as well as in neurodegenerative diseases.

\section{References:}

1. World Health Organization. Risk reduction of cognitive decline and dementia. World Health Organization Guidelines. Geneva: WHO; 2019.

2. Zhavoronkova LA, Kuptsova SB, Zharikova AV, Kushnir EM, Mikhalkova A. [Characteristics of EEG reactivity changes during the performance ofdualtasks by healthysubjects (voluntary postural controland calculation)]. Human Physiology. 2011; 37(6): 688-699 (in Russian). https://doi.org/10.1134/S0362119711060168

3. Bekhtereva V, Craddock M, Müller MM. Attentional bias to affective faces and complex IAPS images in early visual cortex follows emotional cue extraction. Neuroimage. 2015; 112: 254-266. https://doi.org/10.1016/j.neuroimage.2015.03.052

4. Verbraggen F, Logan GD. Automatic and controlled response inhibition: associative learning in the go/ nogo and stop-signal paradigms. Journal of Experimental Psychology: General. 2008; 137(4): 649-672. https://doi.org/10.1037/a0013170

5. Vergunov E, Nikolaeva E, Balioz N, Krivoschekov S. [Lateral preferences as possible phenotypic predictors of reserves of the cardiovascular system and especially sensorimotor integration among climbers]. Human Physiology. 2018; 44(3): 97-108 (in Russian). https://doi.org/10.7868/S0131164618030116 
6. Working Group of the European Society of Cardiology and the North American Society of Stimulation and Electrophysiology. Heart rate variability: measurement standards, physiological interpretation and clinical use. SPb. Institute of Cardiol. Techniques. 2000; p. 82.

7. Luria AR. [Basics of Neuropsychology]. Moscow: Prosveshcheniye; 2004 (in Russian).

8. Dempsey JA, Morgan BJ. Humans in hypoxia: a conspiracy of maladaptation?!. Physiology. 2015; 30(4): 304316. https://doi.org/10.1152/physiol.00007.2015

9. Tomaszewski M, Olchowik G, Olejarz P, Tomaszewska M. The functional lateralization and computer dynamic posturography. Health Prob Civil. 2014; 4(8): 20-26. https://doi.org/10.5114/hpc.2014.57089

10. Kempinsky A. [Psychology of schizophrenia]. St. Petersburg: Juventa. 1998. p. 294 (in Russian).

11. Makarenko MV, Lyzohub VS, Galka MS, Yuhymenko LI, Khomenko SM. [Patent. 96496 State Service for Intellectual Property of Ukraine, MPC A 61B5/16. Method of psychophysiological evaluation of the functional state of the auditory analyzer. No. 2010 02225; stated. 2010 March 1; published 2011 Nov 10, Bul. No. 21] (in Ukrainian).

12. Lyzohub VS, Chernenko NP, Kozhemiako TV, Palabiyik AA, Bezkopylna SV. Age peculiarities of interaction of motor and cognitive brain systems while processing information of different modality and complexity. Regulatory Mechanisms in Biosystems. 2019; 10(3): 288-294. https://doi.org/10.15421/021944

13. Kamenskaya VG, Tomanov LV, Russak YA. Peculiarities of sensory-motor response in girls aged 14-17 with different rates of sexual maturation. Indian Journal of Science and Technology. 2015; 8(29): 1-9. https://doi.org/10.17485/ijst/2015/v8i1/84150

14. Riftine A. Theoretical review and clinical use. Quantitative assessment of the autonomic nervous system based on heart rate variability analysis. Valley Stream, NY: Intellewave, Inc.; 2016. p. 65.

15. Danilova NN, Astafiev SV. [Human attention as a specific correlation between the EEG rhythms and activity of heart rate wave]. Journal of higher nervous activity. 2000; 50(5): 791-800 (in Russian).

16. Guzik P, Piskorski J, Barthel P, Bauer A, Müller A, Junk N, et al. Heart rate deceleration runs for postinfarction risk prediction. Journal of Electrocardiology. 2012; 45(1): 70-76.

https://doi.org/10.1016/j.jelectrocard.2011.08.006

17. Baevsky RM. [Problems of assessing and predicting the functional state of the organism and its development in space medicine]. Uspekhi Fiziologicheskikh Nauk. 2006; 37(3): $43-49$ (in Russian).

18. Gavrilova EA. [Heart rate variability and sports]. Human Physiology. 2016; 42(5): 571-578 (in Russian). https://doi.org/10.1134/S036211971605008X

19. Lyzohub VS, Chernenko NP, Palabiyik AA, Bezkopulna SV. [Method of definitions mental performance during processing of information with different speed of presentation of stimuli]. Cherkasy University Bulletin: Biological Sciences Series. 2018; 1: 70-80 (in Ukrainian). https://doi.org/10.31651/2076-5835-2018-1-1-70-79

20. Ivanitsky AM, Portnov GV, Martynova OV. [Brain mapping in verbal and spatial thinking]. Journal of Higher Nervous Activity. 2013; 63(6): 677-686 (in Russian). https://doi.org/10.7868/S0044467713060075

21. Liston C, McEwen BS, Casey BJ. Psychosocial stress reversibly disrupts prefrontal processing and attentional control. Proceedings of the National Academy of Sciences of the United States of America. 2009; 106(3): 912917. https://doi.org/10.1073/pnas.0807041106

22. Kostandov EA. [Effect of the context on the plasticity of cognitive activity]. Human physiology. 2010; 36(5): 510-517 (in Russian). https://doi.org/10.1134/S0362119710050038

23. Doumas M, Rapp MA, Krampe RT. Working memory and postural control: adult age differences in potential for improvement, task priority, and dual tasking. The Journals of Gerontology: Series B. 2009; 64B(2): 193201. https://doi.org/10.1093/geronb/gbp009

24. Schiller PH. Parallel information processing channels created in the retina. PNAS. 2010; 107(40): 1708717094. https://doi.org/10.1073/pnas.1011782107

25. Moiseenko GA, Vershinina EA, Pronin SV, Chihman VN, Shelepin YE, Mikhailova ES. [Latency of evoked potentials in the tasks involving classification of images after wavelet filtration]. Human Physiology. 2016; 42(6): 37-48 (in Russian). https://doi.org/10.7868/S0131164616060126

26. Porges SW. The polyvagal theory: phylogenetic substrates of a social nervous system. International Journal of Psychophysiology. 2001; 42(2):123-146. https://doi.org/10.1016/S0167-8760(01)00162-3

27. Sears CE, Noble P, Noble D, Paterson DJ. Vagal control of heart rate is modulated by extracellular potassium. Journal of Autonomic Nervous System. 1999; 77(2-3): 164-71. https://doi.org/10.1016/S0165-1838(99)00052-1

28. Ekberg DL. The respiratory gates of man. Journal of Physiology. 2003; 548(2): 339-52.

29. Festinger L. A theory of cognitive dissonance. Stanford, CA: Stanford University Press. 1957; p. 291. 